\begin{tabular}{|c|c|c|c|}
\hline$\underbrace{}_{\text {INESEG }}$ & $\begin{array}{r}\text { International } \\
\text { Res } \\
w w y\end{array}$ & $\begin{array}{l}\text { urnal of Health Services, } \\
\text { rch and Policy } \\
\text { rgipark.org.tr/ijhsrp }\end{array}$ & \\
\hline $\begin{array}{l}\text { ENGINEERING, } \\
\text { SCIENCE AND } \\
\text { EDUCATION GROUP }\end{array}$ & e-ISSN: 2602-3482 & DOI:10.23884/ijhsrp.2019.4.2.05 & IJHSRP \\
\hline
\end{tabular}

Research Article

\title{
INVESTIGATION OF THE EFFECTS OF OCCUPATIONAL HEALTH AND SAFETY BEHAVIOURS ON THE CLIMATE SAFETY OF WORKERS ACCORDING TO PLANNED BEHAVIOUR THEORY
}

\author{
Necmettin ÇIFTC $\dot{I}^{1}{ }^{10},{ }^{*}$ Sonay BíLGİN \\ ${ }^{1}$ Muş Alparslan University, Health Care Services Department, Muş/Turkey \\ ${ }^{2}$ Atatürk University Faculty of Nursing, Department of Public Health Nursing, Erzurum/Turkey \\ *Corresponding author: sonayverepbilgin@ hotmail.com
}

\begin{abstract}
The study was conducted to examine the relationship between safety climate and factors affecting occupational health and safety behaviors of workers. The research was carried out at the Mus Sugar Factory in Mus city center between July 2015 and December 2016. The researchers' universe was formed by 321 workers in the Mus Sugar Factory. To collect data: "Questions about sociodemographic characteristics of workers", 'The scale used to evaluate workers' behavior' and 'Security Climate Scale' were used. The average points of the scale used to evaluate the behavior of the workers were determined to be 122.04 21.840 . The average points of workers' safety climate were found to be $53.87 \pm 11.430$. It was seen that the behavior of the workers was higher than the average of the total points, the gender, the family type did not affect the behavior ( $p>0.05)$, the norms of the chefs, the norms of the workmates and the security behavior affected the security climate $(p<0.05)$.
\end{abstract}

Keywords: Safety behavior, Safety climate, Planned behavior theory, Worker.

Received: March 19, 2019

Accepted: July 24, 2019

\section{Introduction}

Because people are a part of the society in which they live, they are in continuous interaction with their environment. Occupational health and occupational safety concepts addressing all types of physical, psychological and social effects of working order, which is part of everyday life, on people, have arisen. As a result of researches on the healthy and safe working of employees, the subject of protection and development of employees' health has become an extremely important issue [1].

The concept of occupational health first arose from the need to take the relevant measures towards the relationship between occupational life, occupational health, and wellbeing after the wars, and afterward state laid the burden on employers in this field. Thus, the state has begun to make the necessary regulations to provide workers with minimum health and safety measures in the work environment. However, the acceptance of these rights at the constitutional level and their inclusion in international texts had been in the periods following the industrial revolution $[2,3]$.

The employer must provide a safe work environment and is responsible for protecting employees from any hazards (occupational accidents and occupational diseases) that may occur in the workplace $[4,5]$. Occupational health and safety behavior refers to "employees' adaptation to behavioral safety 
routines". These behaviors include safety activities that are a part of legal business roles and procedures and provided by the application of safety policies and procedures, such as the proper use of personal protective equipment, the application of proper business practices to reduce exposure to potential damage and risks [6]. Despite all kinds of technological progress facilitating the living conditions of today, it has not been possible to completely eliminate the probability of accidents and disease [7].

It is accepted that 80-90\% of accidents occurred due to human errors [8]. Human errors are also explained by human behavior and it is considered that defining the components of individual behaviors will help to develop accident-preventing applications and to direct individual behavior to a safe dimension [9].

There are many socio-cognitive models that examine health and safety behavior under behavioral groups which are motivational and based on behavioral animation and multi-layered [10]. Planned behavior theory model that is one of these models is one of the most effective methods used in studies to understand human behavior [11].

Planned behavior theory and its antecedent theory of reasoned action provide cognitive and motivational effects on behavior and also a prediction of behavior. According to the theory, human behavior is under the influence of three factors. These factors are beliefs (behavioral beliefs) about similar behavioral consequences or other features of behavior, beliefs about normative expectations of other individuals (normative beliefs) and beliefs called as "control beliefs" related to the existence of obstructive or progressive factors in the realization of behavior $[12,13]$.

Safety climate is the perception that employees related to the safety of their workplaces and constitutes one of the distinctive features of organizations [14-16].

The safety climate provides a framework for interpreting organizational events and processes related to individual and organizational safety values and for fulfilling daily tasks [17]. It is mentioned that the mutual agreement provided related to the subjects of the safety climate and all the measures to be taken in the work environment positively affects the ability of the employees to properly analyze the accidents and gain experience from the accidents [18]. Efforts to protect, develop and maintain the health of employees require a multi-professional approach. The nurse included in the multi-professional team is the most suitable person to initiate practices in the workplace by monitoring the work environment and the employees during the working together with any changes and by planning any attempts about reason [19].

Therefore, there is a need for an occupational health nurse to know the occupational health and safety behavior of employees working in a factory well, to understand the crux of the problems and to develop approaches for increasing adaptation of workers to work depending on the information obtained.

This study was conducted to determine the relationship between factors affecting occupational health and safety behaviors of workers and safety climate.

\section{Methods}

\subsection{Objective}

The purpose of this study is to determine the relationship between the occupational health and safety behaviors of the employees, their perceptions about the security climate, their attitudes towards occupational health and safety, their defining subjective norms towards occupational health and safety, their perceived behavioral controls on occupational health and safety. 


\subsection{Place and Time of the Study}

It was carried out as a descriptive and correlational study between July 2015 and December 2016 in a factory in Mus city

\section{3. Population and Sample of Study}

The population of the study consists of 321 workers working in the Sugar Factory of Mus City. All the population formed the research sample. 303 people could be contacted due to some reasons such as sickness of workers, their being on leave, being out of shift and not willing to participate in the study.

\section{4. Data Collection Tools}

Question form including the socio-demographic characteristics created by the researcher, scales used in the evaluation of the Behaviour Assessment Scale, Safety Climate scale was used.

\section{5. Socio-Demographic Question Form}

It consists of 9 questions, including gender, age, marital status, family type, educational background, income status and information on working Period.

\section{6. Behaviour Assessment Scale for Workers}

It is basically aimed to determine the occupational health and safety behaviors of the participants in the study and in the direction of this purpose, it has been evaluated the participants'

- Attitudes of workers towards occupational health and safety,

- Descriptive and preventive subjective norms towards the occupational health and safety of the chiefs and their colleagues,

- Behavioral controls perceived towards occupational health and safety,

- Occupational health and safety behaviors.

In the measurement of all the variables mentioned, different scales used by Fugas, Silva and Melia [6], Fugas et al [20], Davis et al [21], Conner and McMillan [22], Burke et al. [23], Hofmann, Morgeson and Gerras were gathered and the scale created was used [24].

- Attitudes of workers towards occupational health and safety:

The attitude scale towards occupational health and safety was measured with a 3-item scale obtained by Fugas et al. [20], Davis et al. [21]. By averaging the scale in their study. Cronbach's Alpha Value of Scale for Attitude is 94. In our study, Cronbach's Alfa value is determined to be 91 .

Descriptive and preventive subjective norms towards the occupational health and safety of the chiefs and their colleagues: It was measured by four 3-item scales developed in the study of Fugas et al. [20]. Cronbach's alpha value of scale; Norms of Chiefs are 92, Norms of Colleagues are 95 dir. Cronbach's alpha value in our study; Norms of the Chiefs are 88 Norms of the Colleagues are 92.

Behavioral controls perceived towards occupational health and safety: It was measured by a 3 -item scale adopted in the studies of Fugas, Silva and Melia [6], Conner and McMillan [22], Cronbach's Alpha Value of Scale is 86. Cronbach's Alpha Value in our study is determşned to be 88 .

Occupational health and safety behaviours: behavior was measured by a scale adapted to measure from 6-items under two subtitles of "adaptation behaviour to safety" and "preventive Safety Behaviour" created by "General-Safety Performance Scale" of Fugas, Silva ve Melia and by the scales of "Safety Citizenship Role Definitions and Behavioural Expressions" of Hofmann, Morgeson and Gerras [24] Cronbach's alpha value of scale for Safety Behaviour is 92. Cronbach's alpha value in our study is determined to be 88 . They were measured according to the "strongly disagree" - "strongly agree" attitudes in 7'Likert scale as the interval. The high score suggests safe behaviour. Lowest 24, highest 168 points are received. 
The scale consists of five sub-dimensions. These are my Department Chief (questions 1-2-3-45-6), which refers to the Norms of the Chiefs, My Colleagues (questions 7-8-9-10-11-12), which refers to the Norms of the Colleagues, During my Work (questions 13-14-15), which refers of Attitude, at my Workplace (16-17-18), which refers to Perceived Behavioural Control, and Soon (questions 19-2021-22-23-24), which indicates the Safety Behaviour.

\subsection{Safety Climate Scale}

A scale has been recommended that was developed by Choudhry, Fang, and Lingard [25] applied in construction companies in Hong Kong and adapted by shortening the safety climate scale. The main reason for this shortening can be explained as follows: while the interest of the management that is the first of two dimensions of the scale of Choudhry, Fang and Lingard [25] and the dimension of employees' participation include positive points related to subject; the second dimension named inappropriate safety and business processes include negative points, and in general terms, the fact that the variables of these two dimensions are opposite expressions to each other. Because the opposite expressions in two different dimensions are approved in terms of the scale development methodology, 8 items from the 22 items have been eliminated and 14-items which are semantically different from each other were determined and used. Validity and reliability of scale have been made by Türen et al., [26] Scale consisting of 14 questions is 5' Likert type one. Options are as follows: "strongly agree", "agree", "neutral" "disagree" "strongly disagree". Two samples have been studied in the reliability and validity study of the scale. Cronbach's alpha coefficients were 0.84 and 0.93 for the first sample; and 0.93 and 0.91 for the second sample, respectively. In this study, the Cronbach's alpha value was found to be 92 . Lowest 14, highest 70 points are received. A high score indicates a high security climate.

\subsection{Research Model of Employees Converted According to the Planned Behaviour Model}

In the model, it is seen that the descriptive and preventive norms of the chiefs merge under the factor of "the Norms of Chiefs"; the descriptive and preventive norms of the Colleagues under the factor of "the Norms of Colleagues" and adaptation to safety behaviour and preventive safety behaviour under the factor of "safety behaviour" (Figure 1.) [27]

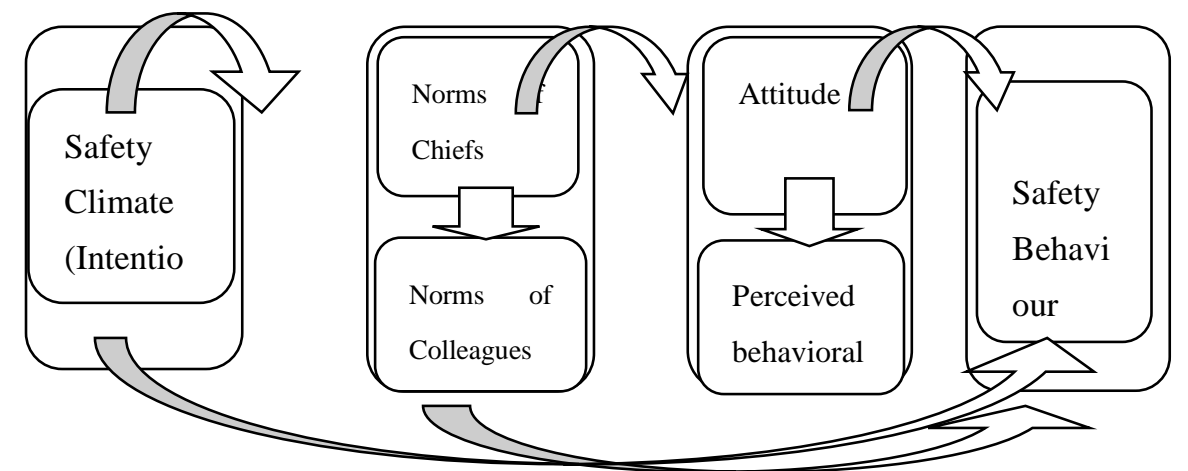

Figure 1. Research Model of Employees converted according to the Planned Behaviour Model

\subsection{Variables of the Study}

Independent Variables; Gender, age, marital status, family type, educational background, income status, working Period in the institution, total working Period, training at workplace related to the occupational health and safety are the independent variables of the workers who participated in the study. Dependent Variables; "Scales used in evaluating workers' behaviour", "Responses to questions related to the Safety Climate Scale" are dependent variables of this study. 


\subsection{Data Collection}

The study data were gathered by the researcher during rest and break times between July 2015 and December 2016 and through approximately 15-20 minutes of face-to-face interview method with workers, when the time could not be enough.

\subsection{Evaluation of Data}

Data codification and their statistical analysis were performed by using Statistical Package for Social Sciences for Windows (SPSS) 22.0, ready statistical package program. Methods used in the evaluation of data obtained as a result of research. Cronbach $\alpha$ reliability coefficient, Percentage distribution and mean, Dunnet Post Hoc test, Kruskall Wallis H test, Mann Whitney U test, t-test in Independent groups, Variance analysis, Pearson Moments Multiplication Correlation.

\subsection{The Ethical Principles for the Study}

Before starting the research, the ethics committee approval and the study permission from the research institution were taken. Workers participating in the study were informed about the study and their informed written consents were received before starting data collection.

\subsection{Limitations of the Study}

Taking workers serving at the factory in study and limitation of the population to the related factory is the most important limitation of this study.

\section{Findings}

The distributions of workers included within the scope of study according to their descriptive features are given in Table 1.

It is seen that $96.4 \%$ of workers participated in study were male, $37 \%$ were $35-44$ years old, $81.5 \%$ were married, $59.4 \%$ had extended family type, $47.2 \%$ were secondary education graduates, $53.8 \%$ had low income, working period of 39.9\% in institution was between 1-3 years, $35.6 \%$ of them was more than 10 years and $64 \%$ of them received training related to the occupational health and safety at the workplace (Table 1).

Table 1. Findings related to the Descriptive Features of Workers included in Study ( $n=323$ )

\begin{tabular}{llll}
\hline & & $\mathrm{S}$ & $\%$ \\
\hline Gender & Female & 11 & 3.6 \\
\hline Age & Male & 292 & 96.4 \\
\hline & $17-24$ & 19 & 6.2 \\
\hline & $25-34$ & 75 & 24.8 \\
\hline & $35-44$ & 112 & 37.0 \\
\hline Marital Status & $45-54$ & 72 & 23.8 \\
\hline Family Type & 55 years old and above & 25 & 8.2 \\
\hline & Married & 247 & 81.5 \\
\hline Educational Background & Single & 56 & 18.5 \\
\hline & Extended Family & 181 & 59.4 \\
\hline & Nuclear Family & 119 & 39.3 \\
\hline & Broken family & 3 & 1.3 \\
\hline & Elementary Education & 37 & 12.2 \\
\hline & Secondary Education & 143 & 47.2 \\
\hline
\end{tabular}


Int. J. of Health Serv. Res. and Policy (2019) 4(2): 110-123

\begin{tabular}{|c|c|c|c|}
\hline & Upper Secondary Education & 93 & 30.7 \\
\hline & Undergraduate Education & 24 & 7.9 \\
\hline & Postgraduate Education & 6 & 2.0 \\
\hline \multirow[t]{4}{*}{ Income status } & Very Low & 5 & 1.7 \\
\hline & Low & 163 & 53.8 \\
\hline & Middle & 48 & 15.8 \\
\hline & High & 87 & 28.7 \\
\hline \multirow{5}{*}{$\begin{array}{l}\text { Working Period in the } \\
\text { institution }\end{array}$} & Less than 1 year & 12 & 4.0 \\
\hline & Between 1-3 years & 121 & 39.9 \\
\hline & Between 3-6 years & 38 & 12.5 \\
\hline & Between 6-10 years & 28 & 9.2 \\
\hline & More than 10 years & 104 & 34.3 \\
\hline \multirow[t]{5}{*}{ Total working Period } & Less than 1 year & 17 & 5.6 \\
\hline & Between 1-3 years & 87 & 28.7 \\
\hline & Between 3-6 years & 63 & 20.8 \\
\hline & Between 6-10 years & 28 & 9.2 \\
\hline & More than 10 years & 108 & 35.6 \\
\hline \multirow{2}{*}{$\begin{array}{l}\text { training at the workplace } \\
\text { related to the occupational } \\
\text { health and safety at workplace }\end{array}$} & Yes & 194 & 64.0 \\
\hline & No & 109 & 36.0 \\
\hline
\end{tabular}

It is seen that the mean score of the Norms of Chief that is a sub-dimension of the Assessment of Workers' Behaviour was 30.04 \pm 7.973 , mean score of the Norms of Colleagues was $28.74 \pm 8.326$, mean score of Attitude is $15.77 \pm 4.723$, mean score of Perceived Behavioural Control was $14.59 \pm 4.886$, mean score of Safety Behaviour was 30.23 \pm 7.759 , mean score of Total Score of Scale used to assess Behaviour of Workers was $122.04 \pm 21.840$ and Total of Safety Climate Scale was $53.87 \pm 11.430$ (Table 2).

Table 2. The arithmetic mean and standard deviation values related to the scores of the Workers' Behaviour Assessment Scale and Safety Climate Scale.

\begin{tabular}{lccc}
\hline & Min & Max & Mean \pm SD \\
\hline The dimension of Norms of Chief & 6 & 42 & $30.04 \pm 7.973$ \\
The dimension of Norms of Colleagues & 6 & 42 & $28.74 \pm 8.326$ \\
Attitude Dimension & 3 & 21 & $15.77 \pm 4.723$ \\
Perceived Behavioural Control Dimension & 3 & 21 & $14.59 \pm 4.886$ \\
Safety Behaviour Dimension & 6 & 42 & $30.23 \pm 7.759$ \\
$\begin{array}{l}\text { Total Score of Scale used to assess Behaviour } \\
\text { of Workers }\end{array}$ & 24 & 168 & $122.04 \pm 21.840$ \\
Total of Safety Climate Scale & 14 & 70 & $53.87 \pm 11.430$ \\
\hline
\end{tabular}

From Table 3 the characteristics of the workers, it was found that there was a direct relationship between their age, their working time, and "the Norms of the Chiefs aspect", "the Norms of Co-workers aspect", "the Attitude aspect", "the Perceived Behavioral Control aspect" and "the Safety Behavior aspect" among the components of Planned Behavior Theory. In terms of "the Safety Climate Scale" 
scores, no relationship was found. From the characteristics of the workers, it was found that there was a relationship between their educational status, income status and total working time, and "the Norms of the Chiefs aspect", "the Norms of Co-workers aspect", "the Attitude aspect", "the Perceived Behavioral Control aspect", "the Safety Behavior aspect" and "the Safety Climate Scale" among the components of Planned Behavior Theory, and it was found to be significant at $p<0.05$ significance level. From the characteristics of the workers, it was found that there was a relationship between their traineeship status related to occupational health and safety, at workplace, and "the Attitude aspect", "The Perceived Behavioral Control aspect", among the components of Planned Behavior Theory, and it was found to be meaningful at $\mathrm{p}<0.05$ significance level. The attitudes during work and behavior Control status of those, who had occupational health and safety-related training at the workplace, are observed to be higher according to those who did not have.

Table 3. Comparison of Workers' Behavioural Assessment Scale and Safety Climate Scale Scores according to their Descriptive Features

\begin{tabular}{|c|c|c|c|c|c|c|c|}
\hline & & $\begin{array}{l}\text { The dimension } \\
\text { of the Norms } \\
\text { of Chiefs }\end{array}$ & $\begin{array}{l}\text { The } \\
\text { dimension of } \\
\text { the Norms of } \\
\text { Colleagues }\end{array}$ & $\begin{array}{c}\text { Attitude } \\
\text { Dimension }\end{array}$ & $\begin{array}{c}\text { Perceived } \\
\text { Behavioural } \\
\text { Dimension }\end{array}$ & $\begin{array}{l}\text { Safety Behaviour } \\
\text { Dimension }\end{array}$ & $\begin{array}{l}\text { Total of Safety } \\
\text { Climate Scale }\end{array}$ \\
\hline & & $\mathrm{X} \pm \mathrm{SD}$ & $\mathrm{X} \pm \mathrm{SD}$ & $\mathrm{X} \pm \mathrm{SD}$ & $\mathrm{X} \pm \mathrm{SD}$ & $\mathrm{X} \pm \mathrm{SD}$ & $\mathrm{X} \pm \mathrm{SD}$ \\
\hline \multirow[t]{3}{*}{ Gender } & Female & $26.73 \pm 5.985$ & $25.45 \pm 7.699$ & $15.55 \pm 5.502$ & $13.00 \pm 4.733$ & $26.27 \pm 7.577$ & $46.64 \pm 12.675$ \\
\hline & Male & $30.16 \pm 8.020$ & $28.86 \pm 8.336$ & $15.78 \pm 4.702$ & $14.65 \pm 4.889$ & $30.38 \pm 7.739$ & $54.15 \pm 11.314$ \\
\hline & $\begin{array}{l}\text { Test and } \\
p \text { value }\end{array}$ & $\begin{array}{l}U=1119.50 \\
P=0.088\end{array}$ & $\begin{array}{r}U=1211.50 \\
P=0.166\end{array}$ & $\begin{array}{r}U=1585.50 \\
P=0.942\end{array}$ & $\begin{array}{l}\mathrm{U}=1279.50 \\
\mathrm{P}=0.250\end{array}$ & $\begin{array}{r}U=1120.50 \\
P=0.088\end{array}$ & $\begin{array}{c}\mathrm{U}=1063.00 \\
\mathrm{P}=0.057\end{array}$ \\
\hline \multirow[t]{6}{*}{$\overline{\text { Age }}$} & $1-17-24$ & $27.74 \pm 7.423$ & $28.00 \pm 6.716$ & $14.53 \pm 5.125$ & $13.32 \pm 5.991$ & $28.11 \pm 7.923$ & $55.21 \pm 11.830$ \\
\hline & $2-25-34$ & $29.24 \pm 7.168$ & $27.63 \pm 8.183$ & $15.17 \pm 5.295$ & $14.00 \pm 5.181$ & $28.91 \pm 8.326$ & $52.39 \pm 11.550$ \\
\hline & $3-35-44$ & $29.29 \pm 7.825$ & $26.89 \pm 8.826$ & $15.08 \pm 4.776$ & $13.79 \pm 4.513$ & $29.36 \pm 7.812$ & $52.53 \pm 11.000$ \\
\hline & $4-45-54$ & $31.46 \pm 7.838$ & $31.28 \pm 7.792$ & $17.29 \pm 3.891$ & $16.03 \pm 4.654$ & $32.32 \pm 6.794$ & $56.42 \pm 10.868$ \\
\hline & $\begin{array}{l}5-55 \text { years } \\
\text { old and }\end{array}$ & $33.44 \pm 10.409$ & $33.60 \pm 5.292$ & $17.20 \pm 3.266$ & $16.84 \pm 3.944$ & $33.76 \pm 6.260$ & $56.04 \pm 13.324$ \\
\hline & $\begin{array}{l}\text { Test and } \\
\mathrm{p} \text { value }\end{array}$ & $\begin{array}{c}K W=17.076 \\
P=0.002\end{array}$ & $\begin{array}{c}\mathrm{KW}=\mathbf{2 4 . 2 0 4} \\
\mathrm{P}=0.000\end{array}$ & $\begin{array}{c}\mathrm{KW}=12.363 \\
P=0.015\end{array}$ & $\begin{array}{c}\text { KW=17.337 } \\
P=0.002\end{array}$ & $\begin{array}{c}\mathrm{KW}=\mathbf{1 4 . 1 2 2} \\
\mathrm{P}=\mathbf{0 . 0 0 7}\end{array}$ & $\begin{array}{c}\mathrm{KW}=8.516 \\
\mathrm{P}=0.074\end{array}$ \\
\hline \multirow{3}{*}{$\begin{array}{l}\text { Marital } \\
\text { Status }\end{array}$} & Married & $30.67 \pm 7.953$ & $28.85 \pm 8.566$ & $15.96 \pm 4.587$ & $14.91 \pm 4.815$ & $30.55 \pm 7.805$ & $53.61 \pm 11.543$ \\
\hline & Single & $27.25 \pm 7.515$ & $28.25 \pm 7.224$ & $14.91 \pm 5.241$ & $13.21 \pm 5.001$ & $28.84 \pm 7.461$ & $55.04 \pm 10.943$ \\
\hline & $\begin{array}{l}\text { Test and } \\
\mathrm{p} \text { value }\end{array}$ & $\begin{array}{l}t=2.933 \\
p=0.004\end{array}$ & $\begin{array}{l}\mathrm{t}=0.486 \\
\mathrm{p}=0.627\end{array}$ & $\begin{array}{l}\mathrm{t}=1.509 \\
\mathrm{p}=0.132\end{array}$ & $\begin{array}{l}t=2.358 \\
p=0.019\end{array}$ & $\begin{array}{l}\mathrm{t}=1.493 \\
\mathrm{p}=0.136\end{array}$ & $\begin{array}{l}\mathrm{t}=0.842 \\
\mathrm{p}=0.401\end{array}$ \\
\hline
\end{tabular}

\begin{tabular}{llllllll}
\hline $\begin{array}{l}\text { Family } \\
\text { Type }\end{array}$ & $\begin{array}{l}\text { Extended } \\
\text { Family }\end{array}$ & $30.64 \pm 8.378$ & $28.92 \pm 8.561$ & $15.92 \pm 4.811$ & $14.92 \pm 4.993$ & $30.61 \pm 7.634$ & $53.70 \pm 11.855$ \\
\hline & $\begin{array}{l}\text { Nuclear } \\
\text { Family }\end{array}$ & $29.12 \pm 7.242$ & $28.47 \pm 8.077$ & $15.46 \pm 4.624$ & $14.19 \pm 4.663$ & $29.83 \pm 7.935$ & $54.10 \pm 10.945$ \\
\hline
\end{tabular}


Int. J. of Health Serv. Res. and Policy (2019) 4(2): 110-123

\begin{tabular}{|c|c|c|c|c|c|c|c|}
\hline & Nuclear Family & $29.12 \pm 7.242$ & $\begin{array}{c}28.47 \pm 8.07 \\
7\end{array}$ & $\begin{array}{c}15.46 \pm 4.62 \\
4\end{array}$ & $\begin{array}{c}14.19 \pm 4.66 \\
3\end{array}$ & $\begin{array}{c}29.83 \pm 7.93 \\
5\end{array}$ & $\begin{array}{c}54.10 \pm 10.9 \\
45\end{array}$ \\
\hline & Broken Family & $29.66 \pm 10.214$ & $\begin{array}{c}28.00 \pm 3.60 \\
5\end{array}$ & $\begin{array}{c}15.66 \pm 3.78 \\
5\end{array}$ & $\begin{array}{c}10.33 \pm 5.50 \\
7\end{array}$ & $\begin{array}{c}23.00 \pm 5.29 \\
1\end{array}$ & $\begin{array}{c}54.66 \pm 1.52 \\
7\end{array}$ \\
\hline & Test and p-value & $\begin{array}{c}\mathrm{KW}=5.743 \\
\mathrm{P}=0.057\end{array}$ & $\begin{array}{c}\mathrm{KW}=1.499 \\
\mathrm{P}=0.779\end{array}$ & $\begin{array}{c}K W=5.113 \\
P=0.573\end{array}$ & $\begin{aligned} \mathrm{KW} & =4.005 \\
\mathrm{P} & =0.135\end{aligned}$ & $\begin{aligned} \mathrm{KW} & =3.903 \\
\mathrm{P} & =0.142\end{aligned}$ & $\begin{array}{l}\mathrm{KW}=.254 \\
\mathrm{P}=0.881\end{array}$ \\
\hline \multirow{6}{*}{$\begin{array}{l}\text { Education } \\
\text { al } \\
\text { Backgroun } \\
\text { d }\end{array}$} & $\begin{array}{l}\text { Elementary } \\
\text { Ed }\end{array}$ & $33.19 \pm 6.983$ & $\begin{array}{c}31.57 \pm 4.87 \\
9\end{array}$ & $\begin{array}{c}16.78 \pm 3.09 \\
2\end{array}$ & $\begin{array}{c}15.76 \pm 3.86 \\
9\end{array}$ & $\begin{array}{c}31.43 \pm 5.81 \\
0\end{array}$ & $\begin{array}{c}56.16 \pm 10.8 \\
49\end{array}$ \\
\hline & Secondary Ed & $30.71 \pm 7.834$ & $\begin{array}{c}29.48 \pm 8.84 \\
3\end{array}$ & $\begin{array}{c}16.80 \pm 4.66 \\
2\end{array}$ & $\begin{array}{c}15.38 \pm 5.03 \\
6\end{array}$ & $\begin{array}{c}31.77 \pm 7.66 \\
9\end{array}$ & $\begin{array}{c}51.74 \pm 11.8 \\
34\end{array}$ \\
\hline & Upper Sec. Ed & $27.01 \pm 8.101$ & $\begin{array}{c}25.18 \pm 7.69 \\
5 \\
\end{array}$ & $\begin{array}{c}13.22 \pm 4.66 \\
0\end{array}$ & $\begin{array}{c}12.59 \pm 4.55 \\
0\end{array}$ & $\begin{array}{c}27.15 \pm 7.78 \\
6 \\
\end{array}$ & $\begin{array}{c}55.23 \pm 10.4 \\
88\end{array}$ \\
\hline & Undergraduate & $31.21 \pm 6.547$ & $\begin{array}{c}32.50 \pm 6.44 \\
7\end{array}$ & $\begin{array}{c}16.96 \pm 3.95 \\
1\end{array}$ & $\begin{array}{c}14.88 \pm 4.81 \\
2\end{array}$ & $\begin{array}{c}30.00 \pm 7.94 \\
0\end{array}$ & $\begin{array}{c}55.63 \pm 12.1 \\
22\end{array}$ \\
\hline & Postgraduate & $36.67 \pm 4.967$ & $\begin{array}{c}33.83 \pm 10.2 \\
65\end{array}$ & $\begin{array}{c}19.67 \pm 2.33 \\
8\end{array}$ & $\begin{array}{c}18.67 \pm 1.96 \\
6\end{array}$ & $\begin{array}{c}35.00 \pm 5.89 \\
9\end{array}$ & $\begin{array}{c}62.67 \pm 7.44 \\
8\end{array}$ \\
\hline & $\begin{array}{l}\text { Test and } \\
\text { p-value }\end{array}$ & $\begin{array}{r}K W=27.279 \\
P=0.000\end{array}$ & $\begin{array}{c}\text { KW=33.56 } \\
3 \\
P=0.000\end{array}$ & $\begin{array}{c}\mathrm{KW}=43.28 \\
0 \\
\mathrm{P}=0.000\end{array}$ & $\begin{array}{c}\mathrm{KW}=26.92 \\
6 \\
P=0.000\end{array}$ & $\begin{array}{c}\mathrm{KW}=\mathbf{2 5 . 5 5} \\
2 \\
\mathbf{P}=\mathbf{0 . 0 0 0}\end{array}$ & $\begin{array}{c}\mathrm{KW}=\mathbf{1 1 . 7 1} \\
5 \\
\mathbf{P}=\mathbf{0 . 0 2 0}\end{array}$ \\
\hline \multirow[t]{5}{*}{$\begin{array}{l}\text { Income } \\
\text { status }\end{array}$} & Very Low & $31.80 \pm 8.758$ & $\begin{array}{c}34.40 \pm 7.05 \\
7\end{array}$ & $\begin{array}{c}18.00 \pm 5.19 \\
6\end{array}$ & $\begin{array}{c}18.80 \pm 1.92 \\
4\end{array}$ & $\begin{array}{c}28.20 \pm 8.40 \\
8\end{array}$ & $\begin{array}{c}52.00 \pm 10.7 \\
00\end{array}$ \\
\hline & Low & $27.65 \pm 7.177$ & $\begin{array}{c}25.63 \pm 7.64 \\
8\end{array}$ & $\begin{array}{c}14.09 \pm 4.70 \\
5\end{array}$ & $\begin{array}{c}12.82 \pm 4.63 \\
6\end{array}$ & $\begin{array}{c}28.34 \pm 7.61 \\
5\end{array}$ & $\begin{array}{c}52.96 \pm 11.1 \\
96\end{array}$ \\
\hline & Middle & $31.52 \pm 7.565$ & $\begin{array}{c}32.04 \pm 6.91 \\
9\end{array}$ & $\begin{array}{c}17.31 \pm 4.27 \\
3\end{array}$ & $\begin{array}{c}16.13 \pm 4.52 \\
7\end{array}$ & $\begin{array}{c}31.33 \pm 7.17 \\
1\end{array}$ & $\begin{array}{c}53.08 \pm 11.7 \\
25\end{array}$ \\
\hline & High & $33.59 \pm 8.149$ & $\begin{array}{c}32.43 \pm 8.04 \\
4\end{array}$ & $\begin{array}{c}17.93 \pm 3.70 \\
7\end{array}$ & $\begin{array}{c}16.84 \pm 4.30 \\
5\end{array}$ & $\begin{array}{c}33.13 \pm 7.40 \\
0\end{array}$ & $\begin{array}{c}56.14 \pm 11.6 \\
12\end{array}$ \\
\hline & $\begin{array}{l}\text { Test and } \\
\text { p-value }\end{array}$ & $\begin{array}{r}K W=43.555 \\
P=0.000\end{array}$ & $\begin{aligned} \mathrm{KW} & =\mathbf{5 8 . 7 4 8} \\
\mathbf{P} & =\mathbf{0 . 0 0 0}\end{aligned}$ & $\begin{array}{c}\mathrm{KW}=\mathbf{4 6 . 5 8} \\
2 \\
\mathrm{P}=0.000\end{array}$ & $\begin{array}{c}K W=51.00 \\
1 \\
P=0.000\end{array}$ & $\begin{array}{c}K W=25.48 \\
6 \\
P=0.000\end{array}$ & $\begin{array}{c}K W=6.351 \\
P=0.000\end{array}$ \\
\hline
\end{tabular}

The working period in the institution

\begin{tabular}{|c|c|c|c|c|c|c|}
\hline Less & $33.33 \pm 7.127$ & $31.17 \pm 6.658$ & $16.58 \pm 4.502$ & $14.08 \pm 6.022$ & $32.58 \pm 4.379$ & $51.33 \pm 13.963$ \\
\hline Betwee & $26.77 \pm 6.957$ & $25.30 \pm 7.966$ & $14.02 \pm 4.596$ & $12.72 \pm 4.646$ & $28.05 \pm 7.937$ & $52.72 \pm 11.129$ \\
\hline Betwee & $30.63 \pm 6.578$ & $27.42 \pm 7.108$ & $14.76 \pm 5.000$ & $14.18 \pm 4.632$ & $29.47 \pm 7.062$ & $53.89 \pm 10.755$ \\
\hline Betwee & $30.64 \pm 9.378$ & $31.82 \pm 7.124$ & $16.36 \pm 4.801$ & $16.29 \pm 4.353$ & $31.32 \pm 7.803$ & $55.43 \pm 11.157$ \\
\hline More & $33.08 \pm 7.913$ & $32.12 \pm 7.988$ & $17.91 \pm 3.854$ & $16.53 \pm 4.417$ & $32.49 \pm 7.434$ & $55.09 \pm 11.802$ \\
\hline $\begin{array}{l}\text { Test } \\
\text { and p- } \\
\text { value }\end{array}$ & $\begin{array}{r}\mathrm{KW}=46.938 \\
P=0.000\end{array}$ & $\begin{array}{l}K W=49.751 \\
P=0.000\end{array}$ & $\begin{array}{c}K W=43.300 \\
P=0.000\end{array}$ & $\begin{array}{l}K W=39.506 \\
P=0.000\end{array}$ & $\begin{array}{l}K W=22.311 \\
P=0.000\end{array}$ & $\begin{array}{l}\mathrm{KW}=3.279 \\
\mathrm{P}=0.512\end{array}$ \\
\hline
\end{tabular}

\begin{tabular}{llllllll}
\hline $\begin{array}{l}\text { Total working } \\
\text { period }\end{array}$ & Less & $29.59 \pm 9.925$ & $31.59 \pm 8.277$ & $17.41 \pm 4.542$ & $16.65 \pm 4.554$ & $30.35 \pm 6.103$ & $48.47 \pm 14.938$ \\
\cline { 2 - 7 } & Betwee & $25.45 \pm 7.539$ & $24.08 \pm 8.691$ & $13.87 \pm 5.002$ & $12.89 \pm 5.038$ & $27.47 \pm 9.001$ & $50.82 \pm 11.996$ \\
\cline { 2 - 7 } & Betwee & $30.35 \pm 5.908$ & $27.97 \pm 5.509$ & $13.81 \pm 4.173$ & $12.54 \pm 4.208$ & $29.84 \pm 5.528$ & $57.92 \pm 7.722$ \\
\cline { 2 - 7 } & Betwee & $30.75 \pm 8.168$ & $29.71 \pm 7.517$ & $16.18 \pm 4.456$ & $15.50 \pm 4.299$ & $30.54 \pm 7.946$ & $54.00 \pm 10.530$ \\
\cline { 2 - 7 } & More & $33.44 \pm 7.277$ & $32.24 \pm 7.807$ & $18.07 \pm 3.696$ & $16.61 \pm 4.370$ & $32.59 \pm 7.324$ & $54.80 \pm 11.594$ \\
\hline
\end{tabular}




\begin{tabular}{|c|c|c|c|c|c|c|c|}
\hline & $\begin{array}{l}\text { Test } \\
\text { and p- } \\
\text { value }\end{array}$ & $\begin{array}{r}\mathrm{KW}=53.243 \\
\mathrm{P}=0.000\end{array}$ & $\begin{array}{r}K W=53.297 \\
P=0.000\end{array}$ & $\begin{aligned} K W & =56.055 \\
P & =0.000\end{aligned}$ & $\begin{aligned} K W & =45.919 \\
P & =0.000\end{aligned}$ & $\begin{aligned} K W & =20.790 \\
P & =0.000\end{aligned}$ & $\begin{array}{c}K W=15.184 \\
P=0.004\end{array}$ \\
\hline \multirow{3}{*}{$\begin{array}{l}\text { Training status } \\
\text { related to } \\
\text { occupational } \\
\text { health and } \\
\text { safety at the } \\
\text { workplace }\end{array}$} & Yes & $29.85 \pm 9.002$ & $28.89 \pm 9.205$ & $16.27 \pm 4.761$ & $15.21 \pm 4.963$ & $30.65 \pm 8.310$ & $54.55 \pm 12.098$ \\
\hline & No & $30.37 \pm 5.726$ & $28.47 \pm 6.506$ & $14.88 \pm 4.543$ & $13.50 \pm 4.568$ & $29.50 \pm 6.638$ & $52.67 \pm 10.073$ \\
\hline & $\begin{array}{l}\text { Test } \\
\text { ind p } \\
\text { ralue }\end{array}$ & $\begin{array}{l}\mathrm{t}=0.609 \\
\mathrm{p}=0.543\end{array}$ & $\begin{array}{l}t=0.467 \\
p=0.641\end{array}$ & $\begin{array}{l}t=2.474 \\
p=0.014\end{array}$ & $\begin{array}{l}t=2.946 \\
p=0.003\end{array}$ & $\begin{array}{l}\mathrm{t}=1.324 \\
\mathrm{p}=0.187\end{array}$ & $\begin{array}{l}\mathrm{t}=1.377 \\
\mathrm{p}=0.169\end{array}$ \\
\hline
\end{tabular}

Table 4. Relationship between Worker's Behaviour Assessment Scale and Safety Climate Scale Score

\begin{tabular}{lcc}
\hline & & Total of Safety Climate Scale \\
\hline The dimension of the Norms of Chiefs & $\mathrm{r}$ & $\mathbf{1 8 1}^{\text {*** }}$ \\
\cline { 2 - 3 } & $\mathrm{p}$ & $\mathbf{, 0 0 2}$ \\
\hline The dimension of the Norms of Colleagues & $\mathrm{r}$ & $\mathbf{2 9 5}^{\text {** }}$ \\
\cline { 2 - 3 } & $\mathrm{p}$ & $\mathbf{, 0 0 0}$ \\
\hline Attitude Dimension & $\mathrm{r}$ &, 083 \\
\hline Perceived Behavioural Dimension & $\mathrm{p}$ &, 148 \\
\hline Safety Behaviour Dimension & $\mathrm{r}$ &, 077 \\
& $\mathrm{p}$ &, 179 \\
\hline
\end{tabular}

$(*) \mathrm{p}<0.05 \quad(* *) \mathrm{p}<0.001$

From Table 4, when we evaluate the relationship between occupational health and safety behavior and safety climate, it is determined that there is no effect of person's attitude and perceived behavioral control in the relationship between safety behavior and safety climate, and it has a direct effect from the descriptive and preventive norms of the supervisors and colleagues at the workplace. In the study, it was determined that the safety climate had an indirect effect on the preventive safety behavior and compliance with the safety behavior, the effect of the security climate on behavior is provided entirely through planned behavioral theory components; the strongest effects on preventive safety behavior were the definitive norms of co-workers $(r=0.295$ and $p<0.0001)$ and the preventive norms of the chiefs $(r$ $=0.181$ and $\mathrm{p}<0.0001)$, and these variables had a fully mediated effect.

\section{Discussion}

Behaviour Assessment Scale for Workers participating study (BASW) was found to be $122.04 \pm$ 21.840. This finding suggests that workers exhibited positive health behaviors, and workers' safe behavior levels were above the median. This result shows that workers have high occupational health and safety behaviors. (Table 2). In the study conducted by Avc1 in the rest area, it is also stated that the mean scores for BASW were above the median [27]. In our study, mean scores of Total of Safety Climate Scale were found to be high as $53.87 \pm 11.43$. This result shows that workers perceive the security climate as high. In the study with healthcare employees by Gül, total safety climate levels were 
found to be high [28]. It was determined that there was a statistically significant difference between the ages of the workers participating study and the mean scores of the BASW sub-dimension, and similar results were found in the studies conducted by Yurtçu and Gyekye and Salminen [29, 30]. In this study, when the workers' Educational Background is discussed; A significant difference was found between the mean scores of all the sub-dimensions of the BASW and this finding indicates that the educational background of the workers is influenced by the chiefs and colleagues and by their exhibition of positive safety behaviors. Studies performed show similar results [28-30]. When the mean scores of the BASW sub-dimension are evaluated according to the educational background of the workers participating in the study; we can say that workers have shown safer behavior as their educational status increases.

It was found that the difference between the mean score of the safety climate scale and education was significant. In the studies of Garcia, Boix and Canosa [31], Hahn and Murphy [32] there was no significant relationship between safety culture/safety climate variables and Educational Background, but in the studies of Gül, Yegin, and Külekçi, it is indicated that educational level effected that safety climate [33-35]. There was a significant relationship between the mean scores of BASW sub-dimension and Income status. It is seen that the workers with high incomes status perceive the norms of the chiefs and the safety behaviors at a higher level. We can say that this result, that is good income status, is effective on sayings of their bosses and on their own behaviors. In the study of Ocaktan with the workers working in the automotive factory, he stated that satisfaction of employees having good and high-income status about the workplace and their perception of occupational safety are influenced positively [36].

A significant relationship was also found between the mean score of the safety climate scale and Income status. It was found that the total mean scores of the workers in the high-income group who participated in the study were higher than the other income groups. In the direction of these results, it can be said that employees who are financially good perceive themselves as safer the workplace. In the study of Ocaktan, it was also stated that more increase in income status, more increase also in safety perceptions [36]. It was determined that the difference between the mean score of BASW sub-dimension of workers and their total working periods was significant. When assessing the sub-dimension mean of THE Safety Behaviour, we can say that those working more than 10 years have higher mean scores than other employees and in the direction of this result, workers exhibited safer behaviors with the more increase in working period. Similar results are also given in the studies of Koç and Kaplancan [37]. The difference between the total score of the safety climate scale and the total working period was found to be statistically significant. In the study of Tüzüner and Özaslan [38] any difference between the total working period and the occupational safety perception at the workplace could not be found, but it was stated in the studies of Ocaktan, Vinodkumar and Bhasi that more working year, more increase in the perception of safety climate [36, 39]. When discussing about receiving training related to occupational health and safety for the mean scores of BASW sub-dimension of workers, a significant difference was found between the mean scores of attitude and perceived behavioral control sub-dimension. (Table 3). It can be said in the direction of these findings that individuals trained on occupational health and safety, in their attitudes about it and in their negative behavioral control, could provide it in a more desired level. While a significant relationship is found in the comparison of the Worker's Behaviour Assessment Scale (BASW) sub-dimension, Dimension of the Norms of Chiefs, Dimension of the Norms of Colleagues and Safety Behaviour Dimension; found that employees have more reliable behavior as their Chiefs and colleagues increase norms and Total of Safety Climate Scale scores, any significant relationship could not be found between Attitude Dimension and Perceived Behavioural Dimension 
(Table 2). It can be said that the Dimension of the Norms of Chiefs, Dimension of the Norms of Colleagues and safety behavior dimension scores shall increase when the score of Total of Safety Climate Scale increases. As the perception of the security climate in the workplace increases, the safety of employees increases. When we evaluate these findings in the direction of the planned behavior model, we can say that the relationship between the safety climate perception and occupational health and safety behavior is not the effect of attitude and perceived behavioral control, but the dimension of the norms of chiefs and safety behavior were affected significantly. (Table 4) We can say that the safety behaviors of workers, Chiefs and colleagues affect both themselves and the safety perception of the workplace. It has been indicated in studies on this subject that safety behavior was effected by the safety climate. We can say that with an increase in safety culture in enterprises, safe behaviors will also increase. In direction of the results of our study, it was determined in the study of Avc1 [27] that the safety climate influenced the norms of chiefs, norms of colleagues, attitude, perceived behavioral control and safety behavior.

\section{Conclusions and Recommendations}

The following results were obtained in the study conducted to examine the effects of occupational health and safety behaviors on safety climate according to workers' planned behavior theory. It was found that

- Workers exhibited moderately safe behaviors,

- Workers had high safety climate perceptions,

- Educational Background, Income status and total working periods of workers affected safety behaviors and safety climate,

- Workers' training status related to occupational health and safety affected attitude and perceived behavioral control,

- Workers with high incomes were found to have a high score in the dimension of the Norms of Chiefs, dimension of Safety behavior and safety climate,

In the direction of these results, it can be recommended;

- to increase the effectiveness of training for occupational health and safety,

- to have personal, especially occupational health nursing staff at the workplaces, for providing counseling services in terms of some features such as safety behaviors of the workers and their educational levels, working period, income status influencing the safety climate

- to do initiative studies towards increasing occupational health behaviors and safety climate

- the organization of supportive programs such as rewarding safe behaviors because of the the behavior of colleagues is important for employees to show safe behavior

- It can be suggested that the personnel working in the field of occupational health should be in the works supporting the safe behavior of the occupational health physician and the occupational health nurse.

\section{Acknowledgments}

The authors acknowledge the contributions of workers taking part in the study. This paper was based on the Master's degree thesis of the first author under the supervision of the second author. This study was presented as an oral presentation at the 32nd Euro Nursing and Medicare Summit in Paris 2017, France. 


\section{References}

[1] Demirel S. Worker's Health and Work Safety, TURK-IS, Publications, 2001.

[2] Arıcı K. Occupational Health and Safety Lessons, TES-IŞ, Trade Union, 1999.

[3] Danna K, Griffin RW, "Health and well-being in the workplace: A review and synthesis of the literature", Journal of management, 25,357-84. 1999.

[4] Bilir N. A "Contemporary Approach to Occupational Health and Safety: Risk Assessment and Risk Management", Journal of Occupational Health and Safety, 25, 9-11. 2005.

[5] Mustafa Ö. Legal, "Criminal and Administrative Liability in Work Accidents", Ankara Bar Association Magazine, 2, 216-222, 2015.

[6] Fugas CS, Silva SA, Meliá JL, "Another look at safety climate and safety behavior: Deepening the cognitive and social mediator mechanisms", Accident Analysis \& Prevention, 45, 468-477, 2012.

[7] Ünal D, Aycan N, "Manisa MAY Textile Industry in the Inc. Examining the reasons for the application of the working workers to the workplace health unit and their sociodemographic characteristics", Journal of Nursing Forum, 6, 49-57, 2003.

[8] Mearns KJ, Flin R “Assessing the state of organizational safety-culture or climate?", Current Psychology, 18, 5-17, 1999.

[9] Lawton R, Parker D, "Individual differences in accident liability: A review and integrative approach", Human Factors, 40, 655-671, 1998.

[10] Armitage CJ, Conner M, "Social cognition models and health behavior: A structured review", Psychology and Health, 15, 173-189, 2000.

[11] Ajzen I, "Perceived behavioral control, self-efficacy, locus of control, and the theory of planned behavior", Journal of applied social psychology, 32, 665-683, 2002.

[12] Fishbein M, Ajzen I, " Belief, attitude, intention, and behavior: An introduction to theory and Research", Philosophy and Rhetoric, 10, 130-132, 1977.

[13] Ajzen I, "The theory of planned behavior", Organizational behavior and human decision processes, 50, 179-211, 1991.

[14] Zohar D, "Safety climate in industrial organizations: theoretical and applied implications", Journal of applied psychology, 65, 96, 1980.

[15] Cooper MD, "Phillips RA. Exploratory analysis of the safety climate and safety behavior relationship", Journal of safety research, 35, 497-512, 2004.

[16] Clarke S, "The relationship between safety climate and safety performance: A meta-analytic review", Journal of Occupational Health Psychology, 11, 315-327, 2006.

[17] Clarke S, “ An integrative model of safety climate: Linking psychological climate and work attitudes to individual safety outcomes using meta-analysis", Journal of Occupational and Organizational Psychology, 83, 553-578, 2010.

[18] Hofmann DA, Stetzer A." The role of safety climate and communication in accident interpretation: Implications for learning from negative events", Academy of management journal, 41(6), 644-657, 1998.

[19] Erci B, Avcı I, Hacıalioğlu N, Kılıç D, Tanrıverdi G. Public Health Nursing. Göktuğ Publishing, Ankara, 306-307, 2014.

[20] Fugas CS, Meliá JL, Silva SA." The "is" and the "ought": how do perceived social norms influence safety behaviors at work?”, Journal of Occupational Health Psychology, 16, 67, 2011. 
[21] Davis LE, Ajzen I, Saunders J, Williams T. "The decision of African American students to complete high school: An application of the theory of planned behavior", Journal of Educational Psychology, 94, 810-819, 2002.

[22] Conner M, McMillan B, "Interaction effects in the theory of planned behavior: Studying cannabis use”, British journal of social psychology, 38, 195-222, 1999.

[23] Burke MJ, Sarpy SA, Tesluk PE, SMITH-CROWE K. "General safety performance: A test of a grounded theoretical model”, Personnel Psychology, 55, 429-457, 2002.

[24] Hofmann DA, Morgeson FP, Gerras SJ. "Climate as a moderator of the relationship between leadermember exchange and content specific citizenship: safety climate as an exemplar", Journal of Applied Psychology, 88, 170-179, 2003.

[25] Choudhry RM, Fang D, Lingard H. "Measuring safety climate of a construction company", Journal of Construction Engineering and Management, 135, 890-899, 2009.

[26] Türen U, Gökmen Y, Tokmak İ, Bekmezci M. "The Reliability and Validity of Safety Climate Scale", Suleyman Demirel University The Journal of Faculty of Economics and Administrative Sciences, 19, 171-190, 2014.

[27] Avc1 C. Examining Employees' Workplace Health And Safety Behaviours In The Scope Of The Safety Climate And The Theory Of Planned Behaviour: a Case Study Of Food and Beverage Departments at Accommodation Enterprises, Gazi University Graduate School Of Social Sciences, Ph D. Thesis, Ankara, 2014.

[28] Demirbilek T. Business Safety Culture, Legal Publishing, İzmir, 2005.

[29] Gyekye SA., Salminen S. "Age and workers' perceptions of workplace safety: A comparative study", The International Journal of Aging and Human Development, 68, 171-184, 2009.

[30] Sar1 FÖ. "Effects of employee training on the occupational safety and health in the accommodation sector", Procedia-Social and Behavioral Sciences, 1, 1865-1870, 2009.

[31] Garcia A, Boix P, Canosa C. "Why do workers behave unsafely at work? Determinants of safe work practices in industrial workers", Occupational and Environmental Medicine, 61, 239-246, 2004.

[32] Hahn SE, Murphy LR. "A short scale for measuring safety climate”, Safety Science, 46, 1047-1066, 2008.

[33] Külekçi B. An Assessment Research of Ship Building İndustry Workers' Occupational Health and Safety Perceptions, Istanbul University, Institute of Social Sciences, Istanbul, Master Thesis, 2012.

[34] Yegin A. The Effects of İndustrial Accidents to The Safety Culture, Gedik University, Institute of Social Sciences, Istanbul, Master Thesis, 2015.

[35] Gül A. A Study on The Correlation Between Safety Climate Culture and Healthcare Workers' Safety Conditions: a Field Research, At1lim University, Institute of Social Sciences, Master Thesis, Ankara, 2015.

[36] Ocaktan M.E. Assesment of Safety Culture in an Automotive Plant, Ankara University, Institute of Health Sciences, Ankara, Ph.D., Thesis, 2009.

[37] Koç T.S. The Effect of Occupational Health and Safety Practices on Organizational Trust and Job Satisfaction: A Study On Accommodation Enterprises İn Alanya, Akdeniz University, Institute of Social Sciences, Antalya, Master Thesis, 2015.

[38] Tüzüner VL, Özaslan BÖ. "A research based on the evaluation of occupational safety and health applications in hospitals", Istanbul University Journal of the School of Business Administration, 40, 138-154, 2011. 
[39] Vinodkumar M, Bhasi M. Safety climate factors and its relationship with accidents and personal attributes in the chemical industry, Safety Science, 47, 659-67, 2009. 